\title{
Formation of Space, Experience and Thought: A Critical Study of Ambedkar's Biopic Bhim Garjana
}

\author{
Sudhir Mehra \\ Assistant Professor, Department of English \& Cultural Studies, \\ E-mail:ssudhir.m@pu.ac.in
}

\begin{abstract}
In his 1936 essay "The Work of Art in the Age of Mechanical Reproduction", Walter Benjamin establishes that it is the 'aestheticization of politics' or 'politicization of art' which streamlines the cultural discourse of a nation at a given moment. The present paper attempts to critically analyze the 'politics of visuality' vis-à-vis 'visuality of politics' as an elemental framework in the making of Indian national discourse. To understand or rationalize this elemental framework, the paper postulates its hypothesis, that the politicization of art is a valid inquiry into how a certain ideological discourse is pre-selected and pre-programmed with a certain grid of features and structures of perception. It is this ideological discourse that needs to be exposed through a visual text namely, Vijay Pawar's Bhim Garjana. This visual text broadly represents what Kancha Illaiah terms the Ambedkarite phase of Dalit history spanning over two decades - 1936-1956. Bhim Garjana is an aesthetic artifact directed by a Dalit himself - an 'insider's'ii document on Ambedkar's life and philosophy. There have so far been three films on Ambedkar including Bhim Garjana, one directed by Jabbar Patel titled Dr. Babasaheb Ambedkar (200o) and second by Anand Patwardha titled Jai Bhim Comrade (2011). All the visual texts though do not follow the definition of biopic strictly, but more or less, the paper places them in the category of biopics. Each text focuses on the life and struggle, both in historical and ideological terms, of Ambedkar.
\end{abstract}

Keywords: Ambedkar, Bhim Garjana, Dalit, Jai Bhim Comrade.

These three visual texts, hereby, provide the multiple vantage views to analyse the politicization of Ambedkar's visuality advancing the discussion in how Ambedkar has been appropriated by different political positions in the modern Indian state from 1936 onwards. This visuality thus gets transformed into an idol, an icon, an obsession, and finally fetish. The reification of Ambedkar in order to manufacture a certain value and belief system which while politicizing the art would inevitably decide the aestheticization of the political economy of the pre- and post-independent brahminic capitalistic state. The second film Dr. Babasaheb Ambedkar is a project sponsored and supported by national film Development Corporation Ltd. and Ministry of Social Justice and Empowerment, Government of India (GoI). The third film Jai Bhim Comrade, though a documentary, depicts both the libertarian and egalitarian social and political philosophy of Ambedkar and its promises and burdens. It attempts being Benjamin-esque in the sense that "communism responds by politicizing art" (242), drawing Ambedkar into the left cultural revolutionary aesthetics by appropriating him as an icon of the labour movement and not any castebased movement.

The paper posits that during the duration 1936-1956, in terms of the representational economy, a certain kind of bourgeoning public sphere $\mathrm{i}^{\mathrm{iii}}$ was in the process of becoming and had not congealed.

(c) AesthetixMS 2021. This Open Access article is published under a Creative Commons Attribution Non-Commercial 4.0 International License (http://creativecommons.org/licenses/by-nc/4.o/), which permits non-commercial re-use, distribution, and reproduction in any medium, provided the original work is properly cited. For citation use the DOI. For commercial re-use, please contact editor@rupkatha.com. 
This public sphere, seemingly, accommodates a 'multi-discursive struggle' towards the conclusive hegemony of one of the discourses over all the other. Gopal Guru observes that the production and reproduction of space, to represent Dalit experience in this public sphere in general and in cinematic form in particular, by the mainstream semiotic ideology is only a "fragmentary form of experience" (72).

The paper, further, states how this production, reproduction, structuring and restructuring of spaces, across time, leads to the constancy and continuation of this fragmentary experience, which first objectivizes and then objectifies the Dalit's subjective lived experience into an object of the cinema. Consequentially, the formed template is merely mechanically reproduced in Hindi popular cinema.

The paper, finally, resolves that this objectification of the lived experience of the Dalit stabilizes Ambedkar as the hero of the Dalit struggle, visualizing the emergence of an alternative or oppositional discourse against the dominant homogenized Gandhian nationalism. It investigates into how the select film visualizes this opposition and how a 'new cultural space' originates and manifests itself in the public sphere of the times. It helps the Dalit dissociate itself off from the tormenting or humiliating meaning produced and determined pertaining to its identity in the dominant and hegemonic Gandhian nationalist cultural space. The space embedded in Dalit experience, thus, becomes the source for the formation and the articulation of thought as well as of the oppositional epistemology against the dominant, hegemonic Gandhian Sarva Dharma Sambhava episteme embedded in the space by the state to homogenize the heterogeneity of the people of India at the moment of conjuncture, i.e., the freedom of India, theorized by Gopal Guru as well.

The paper looks into how the 'experience of Dalit' is represented in cinema. How can this representation be authenticated? Whether this representation is evident or does it have semblance in the socio-economic-political and cultural discourse of the Indian nation-state or not? Thus, a semiotic analysis of the primary text has been attempted with this intent. The paper claims that the subjective experience of the Dalit individual has been objectivized in the space of cinema. The objectivized reality, thus, finds itself in contradiction with the alternative, oppositional or subjective reality of the Dalit subject.

Henri Lefebvre's idea of the "production of space" (171) along with Gopal Guru's observation that a particular "space (is) embedded with experience" leads to "not only the formation of thought but also its articulation" (71). It is this collaboration which forms the foundation of the visual semantics of the present paper.

Lefebvre talks about this experiential space as a culturalized phenomenon and not merely the geography or an empty, socially neutral space. It is thus primarily about controlling people in finite, enclosed and divided sites. It is this conception of space that has epistemological implication for the emergence of social thought in early $20^{\text {th }}$ century India. (Guru 78).

The present paper contextualizes and discusses this distribution / reconfiguration of space through a tripartite formula:iv

1. Cinema as space as art

2. Dalit-space in cinema

3. Dalitized-space in cinema 
The reconfiguration of the nationalist cultural space, thus, injects the idea of 'walking over', 'taking over' or 'walking out' of the dominant space, not only by understanding or cognitively mapping the experience but also through its intensification through an abstract language (73). This intensification, for our purpose, will be made visible through the visual architectonic of the film played out in its "chronotope of ordeal" (Alexander 27) - as associated with the journey of 'rise and fall', 'ascent and descent', 'hope and despair' of Ambedkar.

\section{Vijay Pawar's Bhim Garjana (1989)}

Opening image (fig.1) of the film represents the 'heterogeneous folkloric cinematic moment'. The foreground of self-flagellation against the darkened background space, crescendo music (continuously rising in pitch) and the projection of violence in the very first scene seeks to restructure the conventional space of cinema in an alternative way (Conventionally, the feature films in popular Hindi cinema opens with the images of Hindu gods and goddesses seeking blessings for the success of the films). For instance, in place of a prayer, inclusion of the violence, in the form of self-flagellation, is suggestive of the attempt to liberate the cinematic form from its rigid homogenized and hegemonized spatial organization through a very bold redefining or redeciding of what is 'to be' and what is 'not to be' shown to the audience.

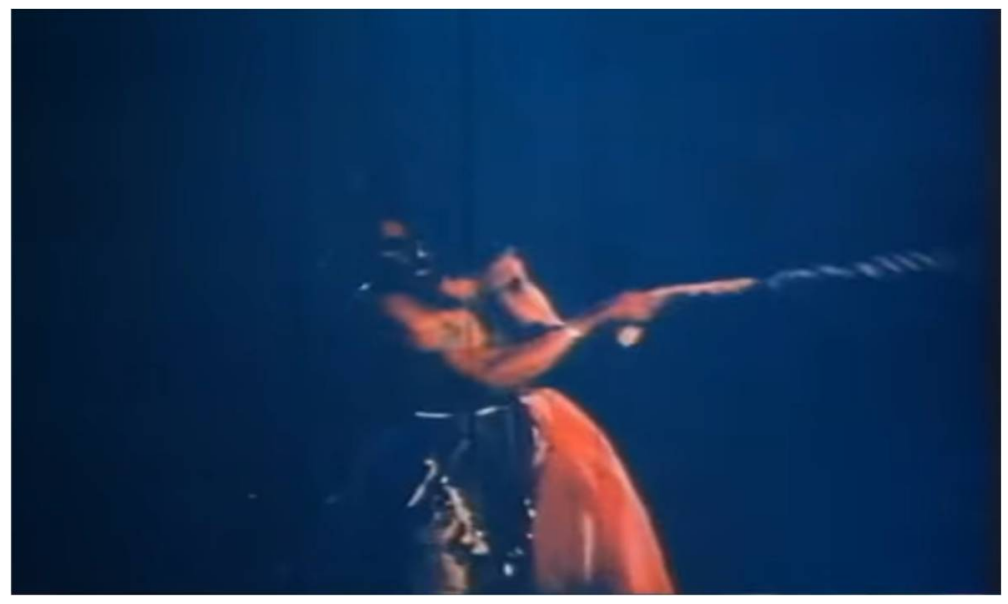

Fig. 1. Still from Pawar, See Bhim Garjana (oo:0o:19)

Like a nishachar a Dalit, comes out of the darkness symbolic of how the Dalit experience must become visible in the cinematic space which hitherto has been invisibilised strategically by the dominant Hindu semiotic ideology.

In other words, it is an attempt to articulate the complex relationship of the invisible body of the untouchable-Dalit with a cultural space, i.e., the space of cinema. It further suggests that it is not only the space of mainstream popular Hindi cinema that is quarantined to the Dalit but also the space of the category Dalit that remains quarantined for them. Pawar attempts to secure and open this quarantined space through the "dramatic dynamization of the space" (32) - a dynamism deployed by the filmmaker to transform the "negative space" (32) (of fall and despair - blackness) into a "positive space" (32) (of rise and hope - light falling on the character). This dynamism helps the filmmaker in the spatial organization of Bhim Garjana's "semantic, dramatic, visual and [ideological] narrative structure" (29).

The second cinematic image (fig.2) in terms of patronage is shown of Shahuji Maharaj, Mahatma Jyotiba Phule, Periyar Ramaswamy and a very close friend of Ambedkar, Shreedhar Pant Tilak. The invocation is more secular than sacred breaking the already established or 
conventionally followed dominant patterns of invocation, for example invoking Goddess Saraswati or God Ganesha as mentioned earlier. This implies the transformation in the "architectonics of the cinematic signification" (29).
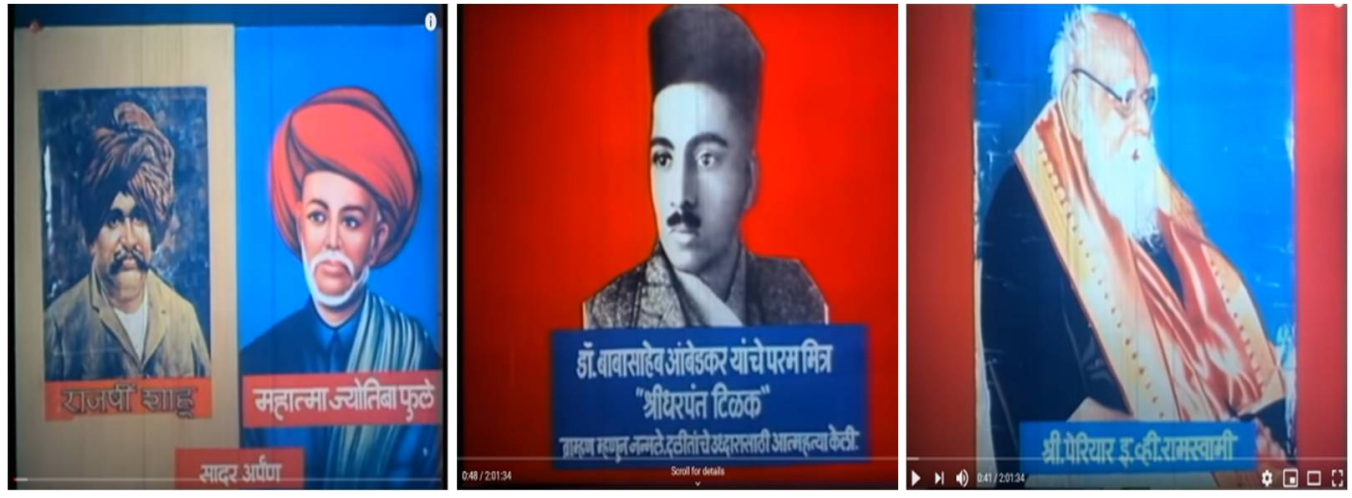

Fig. 2. Still from Pawar, Bhim Garjana (oo:00:38 - 00:00:48)

The visual structure of Vijay Pawar's film breaks the conventionality of the structures of mainstream films in the popular Hindi cinema by reorganizing its spatiality by acknowledging the presence of hitherto unacknowledged and disregarded legislators of humanity. Pawar's visualization, following Gopal Guru's paradigm of mobilization and emancipation, does not merely visibilize the normative limit of static and old space of mobilization but also promises to develop the vocabulary of emancipation which is delivered when he projects a multitude of people at one instance followed by the photographic image of Ambedkar and the ones of his followers on foot and the ones laden on the roof of trains. This sequence is extended across for a few minutes, rendering this scene to be an exemplary one, encrypting a message (fig. 3).
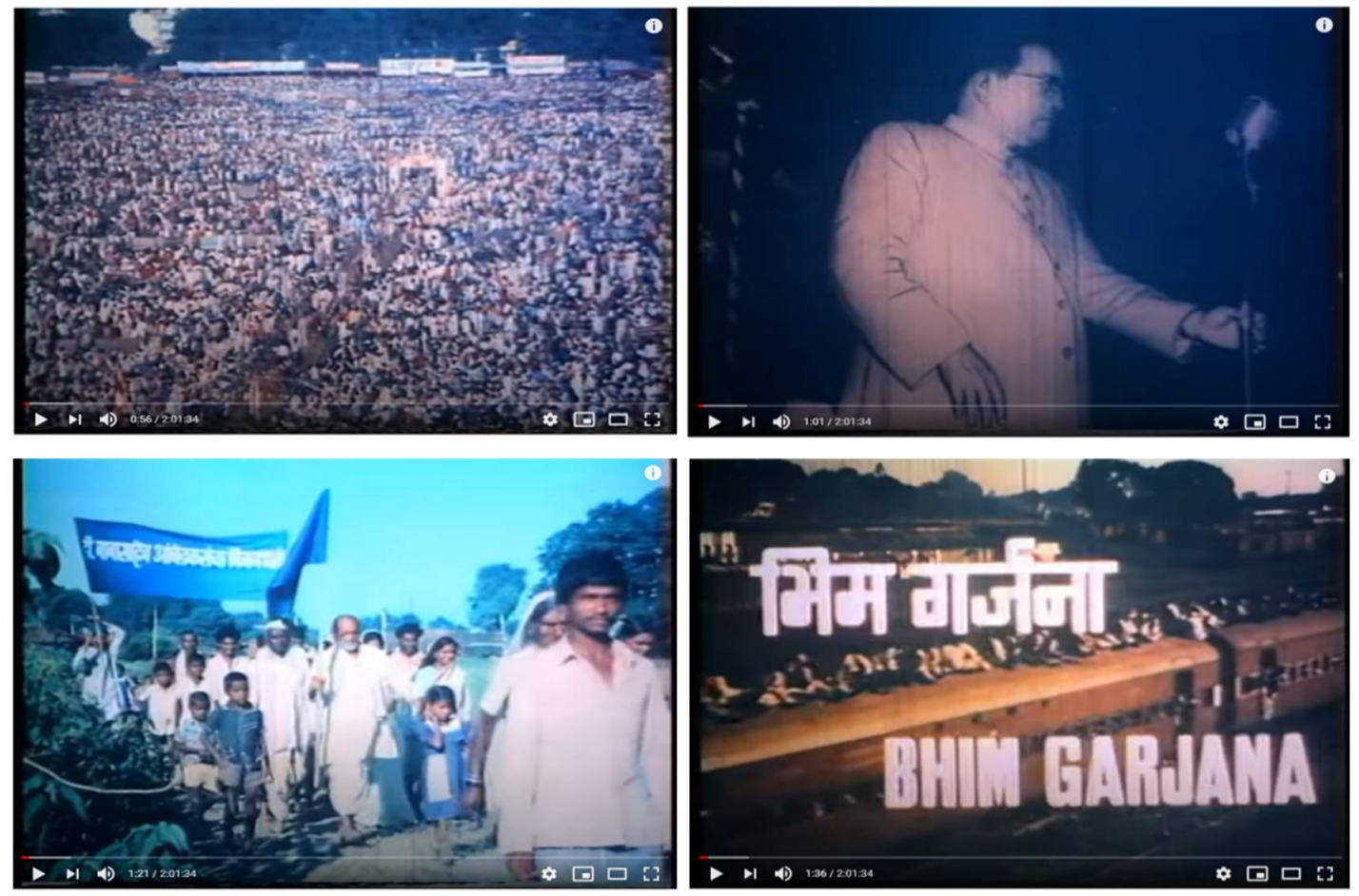

Fig. 3. Still from Pawar, see Bhim Garjana (oo:0o:56- oo:01:41) 
The message that the future of Dalits is not to be redeemed by the moral, ahistorical and thus mystical category of Gandhi (which invokes the idea of seva, i.e., service for the intra-group solidarity for the political conjuncture of India's Independence) rather it is the political category of swabhiman or aatm-samaan (self-respect) invoked by Ambedkar which will be the source of the transformation of Bahishkrut Bharat ${ }^{v i}$ (the India of excluded-untouchables) into Prabuddha Bharat $^{\text {vii }}$ (the India of the enlightened people) (Guru 75).

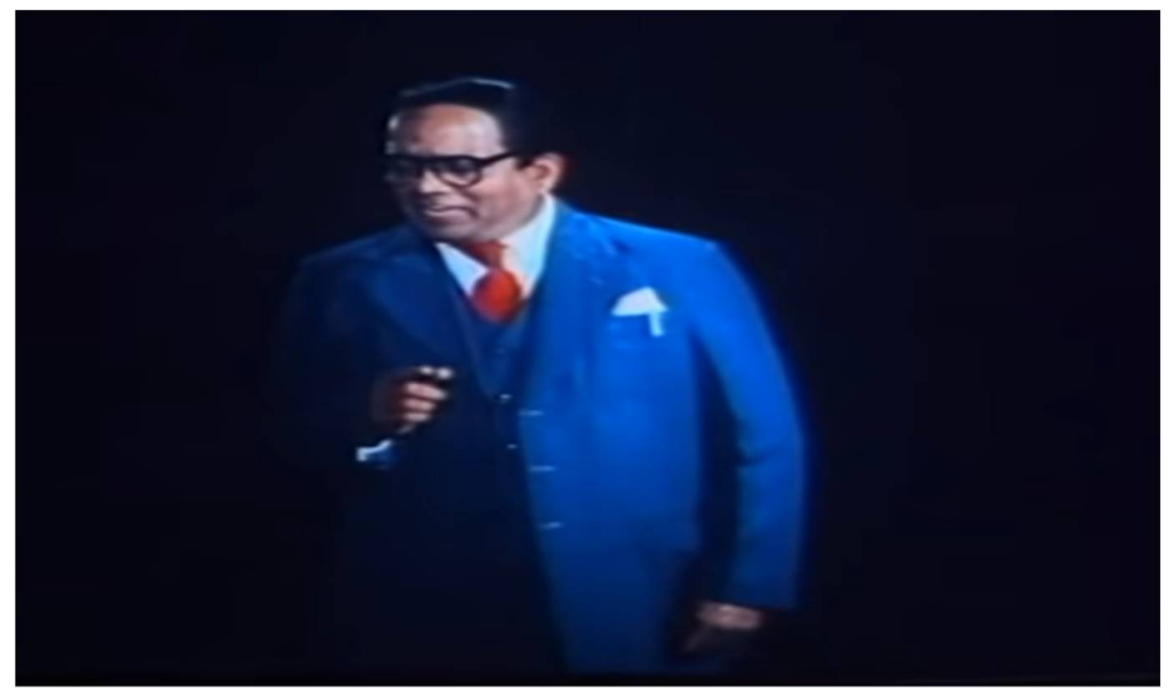

Fig. 4. Still from Pawar, see Bhim Garjana (oo:05:30)

Ambedkar dressed in the blue suit, historically, revisits the status of Dalits in his speech (fig.4). The speech that encapsulates a message to his people imagining Prabuddha Bharat, which he promises can only emerge from the critical re-appropriation of "heterodox traditions"viii and through the idioms of modernity and mobility ${ }^{\mathrm{ix}}$. These idioms are characterized and replicated in the film in thousands of people sitting on the moving train. The heterogeneity of masses represents the people of India. Essentially, the symbols of train and the suit not only signify western modernity and mobility rather they suggest that the people must move out of their 'quarantined spaces'. It is this mobility that promises to initiate the movement towards the realization of the possibility of change or transformation to different possible lived experiences, i.e., towards Ambedkar's Prabuddha Bharat.

The presence of Dalit, i.e., Ambedkar in the office [public] space and the visibility of a Dalit character, i.e., Krishnanand (playing Ambedkar's role in the film) on the cinematic space [public sphere] both lead to a mandatory sterilization with gau-mutra (cow-urine) as both the spaces had hitherto been prevented or preserved from being corrupted by the presence and visibility of the Dalit body in the office [public] space and on the cinema screen [public sphere] respectively. Pawar, however, depicts that Ambedkar walks out of both the spaces leaving both the spaces and cow urine to be "counter-sterilized" (8o) against the pollution. 


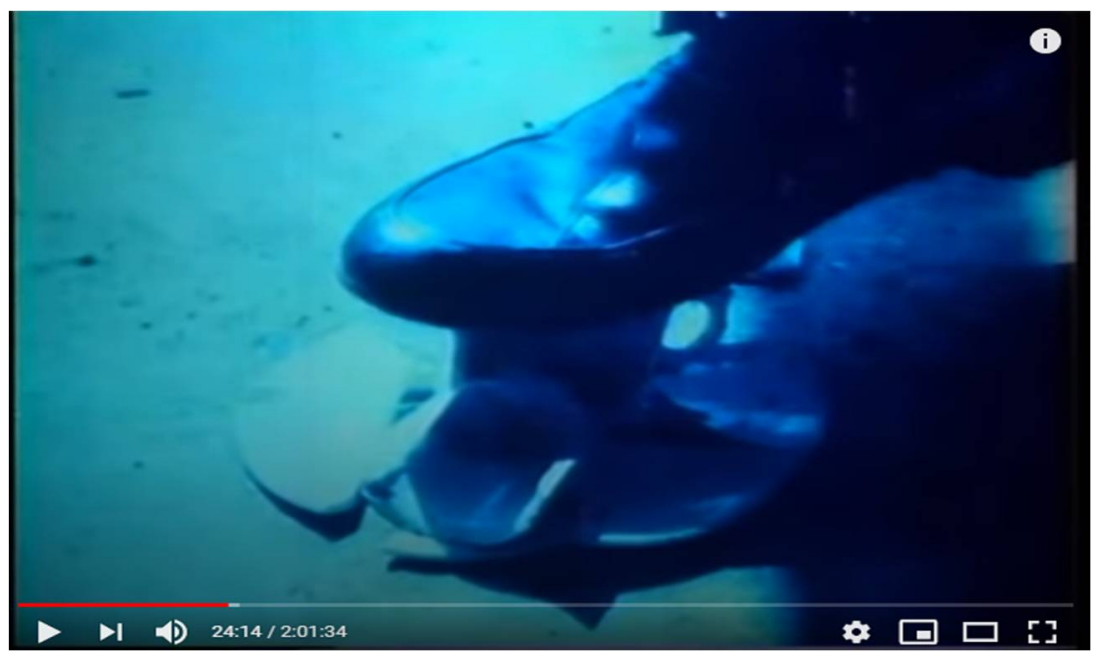

Fig. 5. Still from Pawar, see Bhim Garjana (oo:24:14)

Another such incident of social humiliation, at staff club, based on the chatur-varna system of Hindu society incited Ambedkar to walk out of the space occupied by the caste Hindus and Muslims without saying anything but not without organizing an act of crushing the saucer under his foot, signifying the very counter-humiliation of the caste-based orthodoxy (fig.5).

These two incidents of pollution and humiliation historically necessitated the idea of developing a response system, hitherto not conceived and recognized by the Dalits for any correspondence between the caste Hindus and the outcastes in both the space signified by the office or staff club and the space assumed by the cinema as a part and parcel of the socio-political and cultural public sphere. In this way, Pawar manages the "visual economy" (Poole 9), to intensify the act of claiming of space by the excluded, knowing that the production and conservation of space becomes a necessary condition for the oppressor to sustain a particular kind of experience that can morally paralyze the victim, who in the present case is Ambedkar. Thus, Ambedkar, instead of being morally paralyzed, succeeds in developing the 'new non-submissive response system' that thwarts the conservation of the orthodox power nuances of the sociology of the club/office space.

This rationally active "chronotope" (Alexander 29) emerging from the spaces of club/office generates an ideological movement over the dominance inherent in the space represented by Ambedkar's act of walking over the crushed saucer. It enables the character in terms of assuming the authorship of his lived experience instead of projecting only the elements of fall, descent, despair and thus becoming an active social agent in determining the course of his existence. It is the cinematographic movement of the character which engenders the potential and possibility of this mobility, moving out of the servile conditions of existence towards something more promising and more ethical-political motivating categories premised on the values of dignity, self-respect, freedom, equality, social justice.

Quite interestingly, the "chronotope of rise-fall, ascent-descent, and hope-despair" (31) represents Ambedkar's journey, through the fall, despair and descent, as the objectified experience of Dalit. As a reflective wrong of the right, the subjective experience of the victim (Dalit) is produced objectively. This subjective is to be represented with and against the objective. Moreover, this 'with' and 'against' are to be done through the reconfiguration or the ideological restructuring of spaces through the visual architectonic representing the fragmentary form of experience of the Dalit. It is fragmentary because it is objectively produced in the space of the mainstream popular Hindi cinema and also because the space provided to Dalit in the cinematic form can only be represented 
by yoking it with/against the other. It is fragmentary because the perceptual schemata of the dominant are not equipped enough to read the cultural knowledge of the Dalit in the space of cinema. It also lacks the approach to critically assess and represent both the Dalit in the cinema and the space created by the Dalit, both in cinema and public sphere. Moreover, it is fragmentary because the experiential reality and its effective resultant have a definite bearing on the formation of social thinking.

Gopal Guru extracts support from Lefebvre to suggest that the space is to be seen and interpreted in terms of the body, because this bodily space is "experienced in its depths as duplications, echoes or reverberations" (Guru 81). He further quotes Lefebvre: "space is in my body and then it is my body's counterpart or "other", it's my mirror image or shadow" (81) to support his argument how it becomes relevant for understanding the shadow of an untouchable (81). For instance, during the 18th century, under Peshwa Rule, the body of an untouchable and its show/ presence/ appearance worked together to produce a humiliating experience for the dominant Brahmins. In this way, the real Brahmin and the reflected/echoed/ mirrored/realized Dalit becomes equally powerful in mapping the space but in favor of the socially dominant caste. It is in this mapping, where both being powerful for each other's existence, that the fragmentary form of experience of the Dalits has been produced and reproduced. The stability and continuation, of this production and reproduction, has been of both the symbolic-dramatic-psychological-cinematographic image of Ambedkar and the socio-political and cultural philosophy of Ambedkar.

In other words, the experiential space of Ambedkar need not to be seen to stand in isolation rather his manufactured fragmentary experience will be compensated by the inevitable presence of his other that is Gandhi, in the Gandhi Ambedkar binary. Both, Ambedkar and Gandhi, represent emancipatory projects but the qualitative ideological presumptions of both are different, while Gandhi invokes the category of moral, Ambedkar, in turn, takes help of rational. For Gandhi, it is the rectification and recovery of space from Britishers and the category of 'moral', for mobilization of people, by invoking the idea of seva (self-less public service) trusteeship, care, co-operation by identifying with people (Guru 75). Anubhava (experience) and Achar (practice) by identifying with people will lead to the production of a historical conjuncture, namely, India's Independence (88). The dissemination of this dominant, homogenized ideological intent is what Ambedkar is shown to be particularly against. "Gandhi's experiment with the experiences of self and others" (75) is what Ambedkar becomes foil to. Both Guru and Sarrukai in their conclusion also establishes the fact that for Ambedkar it is not the rectification or recovery of the space rather it is the radical subversion of the space allocated to him and his community that matters. For total mobilization, Ambedkar does not have to resort to experiments to produce a homogeneous experience for everyone because in the very end what he is committed to is not to produce historical conjuncture but something which is more dexterous and holistic. First and foremost, Ambedkar's fight for liberation of the untouchables who are pushed into the dark-hole is to be recognized as human beings with a sense of self-respect, dignity, freedom, liberation, equality.

For Ambedkar, reason is to be deployed not like Gandhi, who uses it as the moral category, deliberately recovered internally from the tradition, but it is to be used from both the perspectives, internally to recover the "heterodox traditions such as of Buddha, Kabir, Jyotiba Phule and externally in terms of western colonial modernity" (74). Though Ambedkar's tradition is also embedded into "agnostic territory" (76) but it does not stay there rather it moves out into emancipatory spheres. This movement from internal to external is shown in Ambedkar's choice of the modern vocabulary, definitely used to make a dent in the local configuration of power around the coordinates - Brahiminism and Capitalism. 
The anubhava or experience of self-respect and social justice became the "primary epistemological source for alternative imagination and politics of emancipation" (Guru 89). The modern vocabulary utilized by Ambedkar like manuski (self-respect), mankhandana (humiliation), puraskrut (harmonious), bahiskrut (ostracized), adhikar (rights), seva (service), shram (labour), vethegari (unpaid-labour) makes us aware about the limitations of Gandhian vocabulary of sewa, shuddhi, sarva-dharma-sambhava (89). The burning of The Manusmriti by Ambedkar precisely projects the annihilation of the cognitive and conceptual vocabulary of caste-Hindus through which the entire civilization of Dalits has been annihilated. Anubhava, as a conceptual category embedded in Ambedkar's domestic experiential space, does tell us about the mobility Ambedkar wants to bring in for the Dalits. Markers of this mobility are Ambedkar's attempts to make his wife learn and 'educate' herself, giving pen to his son Rajratan (fig.6).

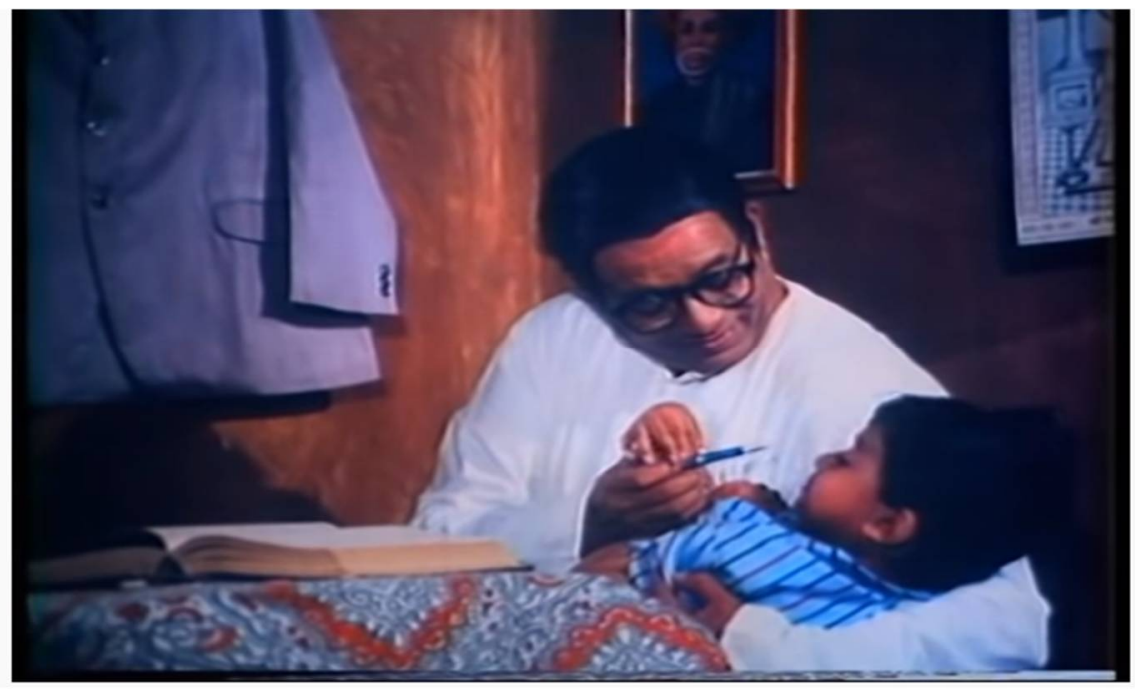

Fig. 6. Still from Pawar, see Bhim Garjana (oo:51:48)

In this cinematic image, the background has been made darker, except the light projected on his suit and the table on which Ambedkar studies. This is the intensification of the struggle - struggle to survive, to read, to educate, to complete the degree. Ambedkar was forced to return when Baroda state withdrew his scholarship in the middle of the course. This intensification visualizes or cinematically imagines the ontological wound of 'immobility' produced and reproduced in the history in the anubhava of Dalits.

Another such intensification of the pain caused by the incident of diarrhea due to which a lot of Dalit children died for not having access to safe drinking water. The pain of this wound caused him to take the decision of Mahad Satyagraha. ${ }^{x}$ The decision announced at Solapur meeting of Bahiskrit Hitkarnni Sabha ${ }^{x i}$ resulted into the production of an exclusive political space for the Dalit self. Here Ambedkar insists that 'agitation' is the only means for the depressed classes to achieve their political rights and their right to freedom. 


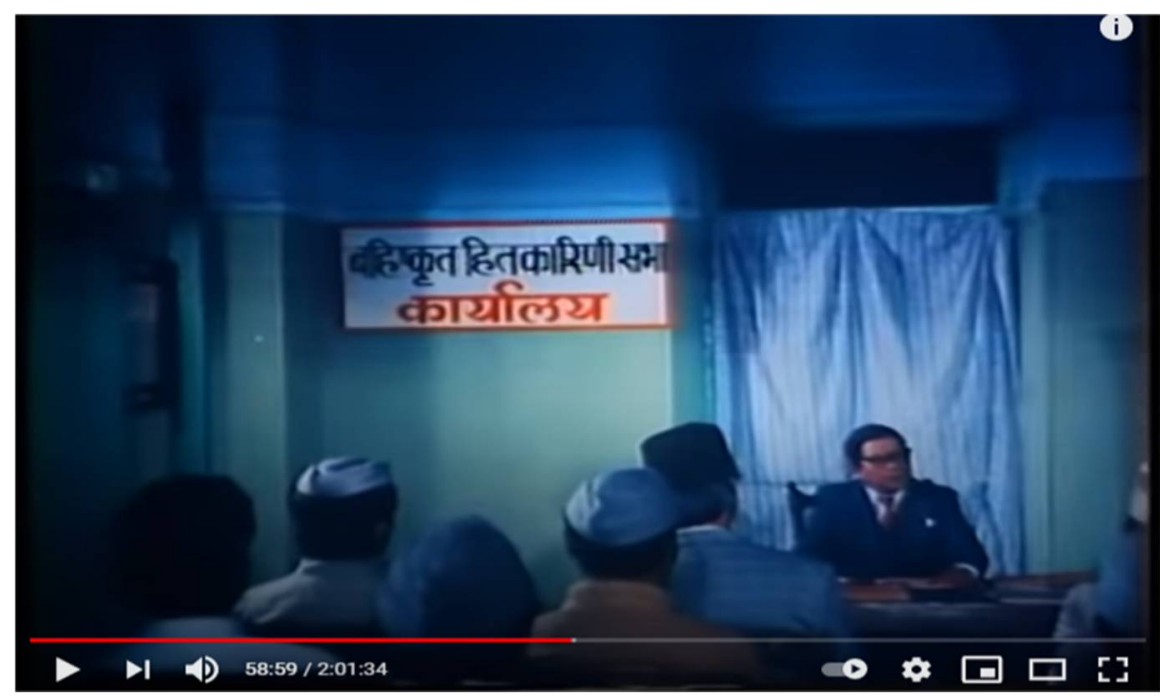

Fig. 7. Still from Pawar, see Bhim Garjana (oo:58:59)

Ambedkar asserts that for this agitation Dalits have to organize and mobilize as visualized and projected (through the collective march and sloganeering of people) in the film. The Solapur meeting followed by another meeting organized by Kolaba Jila Bahishkrit Parishad prepares ground for further mobilization where Ambedkar is shown addressing the people from Vireshwar Theatre, a new and open space which unfolds theoretical and political promise through the iconic call given by Ambedkar, i.e., "educate, organize, and agitate" xii (fig.7).

Ambedkar recommends that Dalits need Aachar, Vichar aur Uuchar ki Shudhi (atonement of conduct, thought and utterance). The secular space is being restructured into an opportunity-space which generates the possibility of restoring dignity to Dalits. Ambedkar asserts that one way to restore dignity to Dalits is to ensure their representation in government jobs for which primary and secondary education is important, that they stop eating the meat of dead animals, stop being dependent on others, start cleaning the places they live in, start wearing clean clothes and make hygiene a habit for everyone, leave discrimination among themselves, they need to learn swavlamban (self-help).

The gathered crowd of followers led by Ambedkar reaches the prohibited space in a procession shouting slogans, dancing, celebrating their assertion. The space which hitherto was prohibited has produced a new experience for the Dalits in terms of justice, equality and secularism. This equality asserted by drinking the water from the pond meets with an inevitable and violent resistance from the caste Hindus. Ambedkar warns caste Hindu population against such insanity which if repeated will be met with more spirited response from the Dalits. During his next address at Vishweshwar Theatre Ambedkar informs his followers that the caste-Hindus who attacked Dalits during Mahad Satyagraha have been tried in court and imprisoned (fig.8). This new and liberating experience instilled a sense of achievement of justice. Further, Ambedkar invokes the concept of Sarvabhuti Ekatama (all are one), so if justice can be secured for some it can also be secured for a lot of people because the law is equal for all. Ambedkar also illuminates the gathering about the fact that the act of drinking water from Mahad is not going to immortalize them. The act is merely deliberated towards the recognition of the presence of untouchables (in public sphere as a valid identity) by the one-dimensional imagination of caste-Hindus (fig.9). 


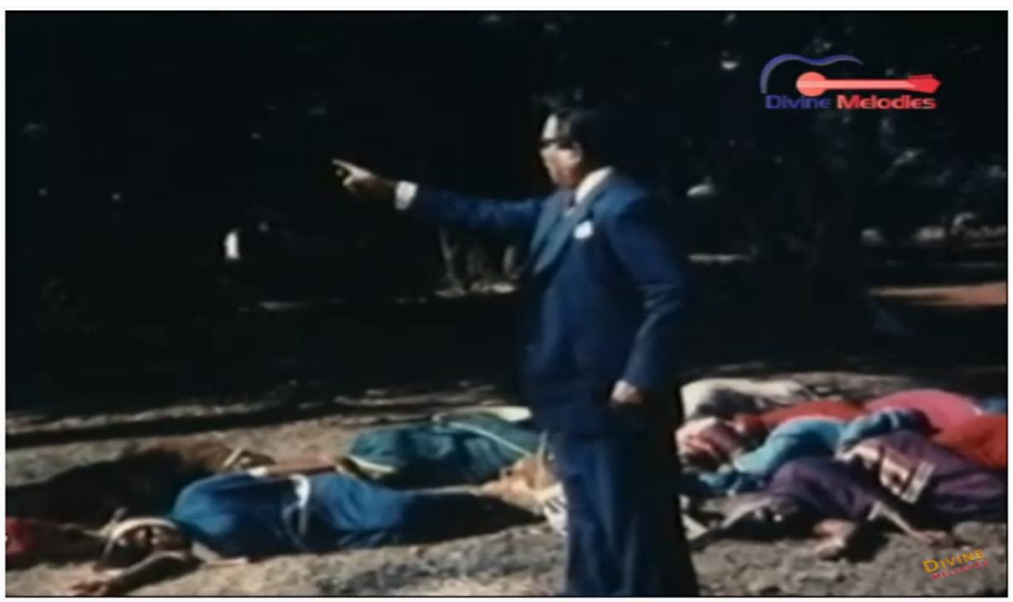

Fig. 8. Still from Pawar, see Bhim Garjana (o1:13:21)

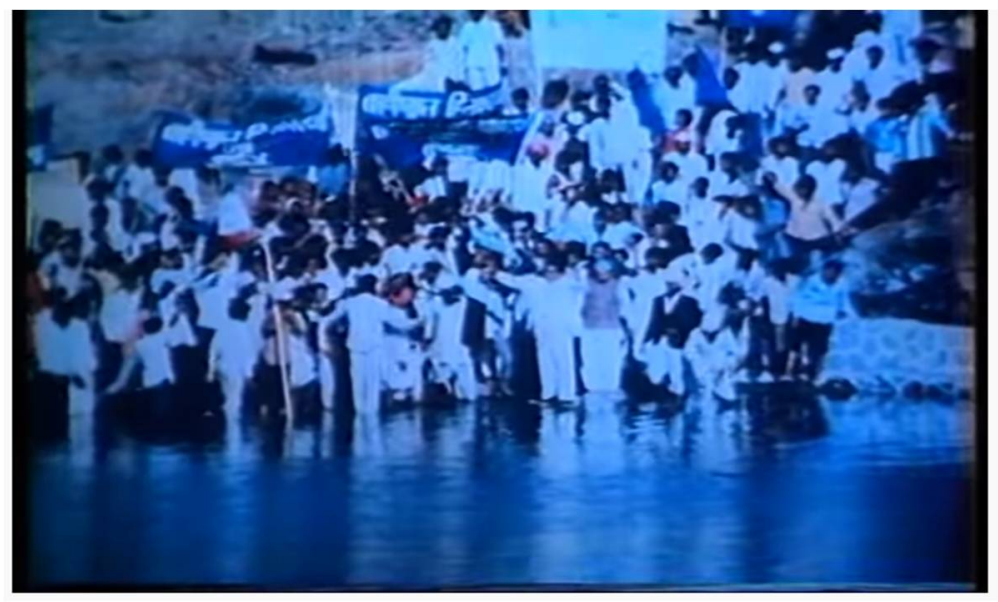

Fig. 9. Still from Pawar, see Bhim Garjana (01:07:49)

Pawar visualizes Gandhi Ambedkar correspondence on the question of representation. Gandhi opposes Ambedkar's view on the subject of separate electoral for depressed classes (Dalits).

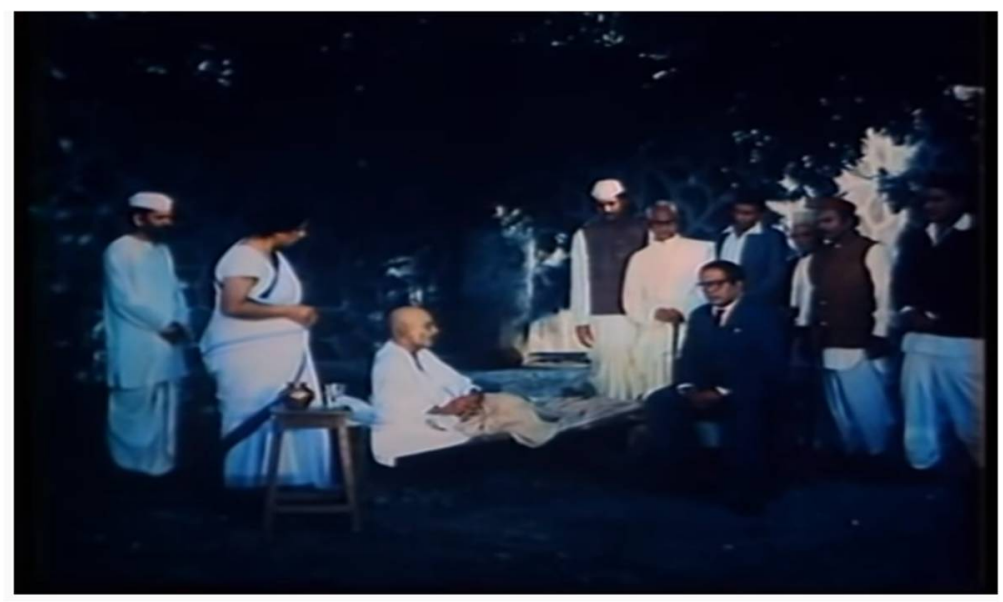

Fig. 10. Still from Pawar, see Bhim Garjana (o1:30:25) 
Pawar visualizes the visual semantics of the correspondence in a manner so as to reveal the "politics of position/posture'. The significance of the open space and the inherent 'closed-ness' of the Gandhi's position on the question of separate electorate is apparent (fig.10). Pawar's further intensifies the visual through the verbal correspondence.

Ambedkar: Gandhi ji, you are doing injustice to us.

Gandhi: It is my misfortune that whenever I do anything it is always considered as injustice to you

Ambedkar: I am not ready to surrender the right to separate electorate awarded by government to dalits. I seek rights for Dalits not patronization.

Gandhi: I don't wish to segregate Dalits from the Hindu fold.

Ambedkar: The right to separate electorate has not only been granted to Dalits. It has been granted to Christians, Mohammeden, Anglo-Indian and Sikhs as well.

Ambedkar: If separate electorate to Sikhs and Muslims does not break the country then how this privilege to Dalits will prove dangerous to the integrity of India.

Gandhi: You are absolutely right. I agree with what you say. You are untouchable by birth. I am untouchable by heart. I cannot let the country be divided on the basis of factionalism based on caste even if my life has been put on the stake. Untouchables are a part of Hinduism only and will remain so.

Ambedkar: But I will never surrender the rights of millions of my untouchable brethren at any cost.

(Ambedkar walks out) (o1:30:10- 01:31:20)

The act of walking out from the cinematic space gestures Ambedkar's wish to walk out of the Hindu fold that precisely is the wish of Gandhi as verbalized in the dialogues as well. Pawar attempts to depict the latent breathlessness of Dalits in the 'closed-ness' of the Hindu society. At another level of significance, it is this wish to walk out that finally concludes in his conversion to Buddhism. Ambedkar's walking out also signifies a movement out from a negative, malafide, improvised, manipulative, Manuwadi, Brahminic, Vedantic, and Hinduised space.

Gandhi's anxiety pertaining to allocation of separate electorate to Dalits, at another level of significance, merely foregrounds Gandhi imagination of Indian nation space in terms of Ramrajya (rule of king Rama). Gandhi's imagined nation automatically presumes the 'uniformity of social and cultural conditions' of daridarinarayan, the peasant and harijan, the untouchable (Guru 102). Whereas, in Ambedkar's sense of reality, based on the essential heterogeneity of experiential spaces, no such uniformity exists.

Pawar, thus, can be said to have attempted to visualize both Gandhi's belief and Ambedkar's disbelief in uniformity and he manages to establish the essential 'spatial' difference at all levels - social, political, cultural, ideological, philosophical etc. - between Gandhi and Ambedkar, as discussed by Gopal Guru $(74,75)$ 


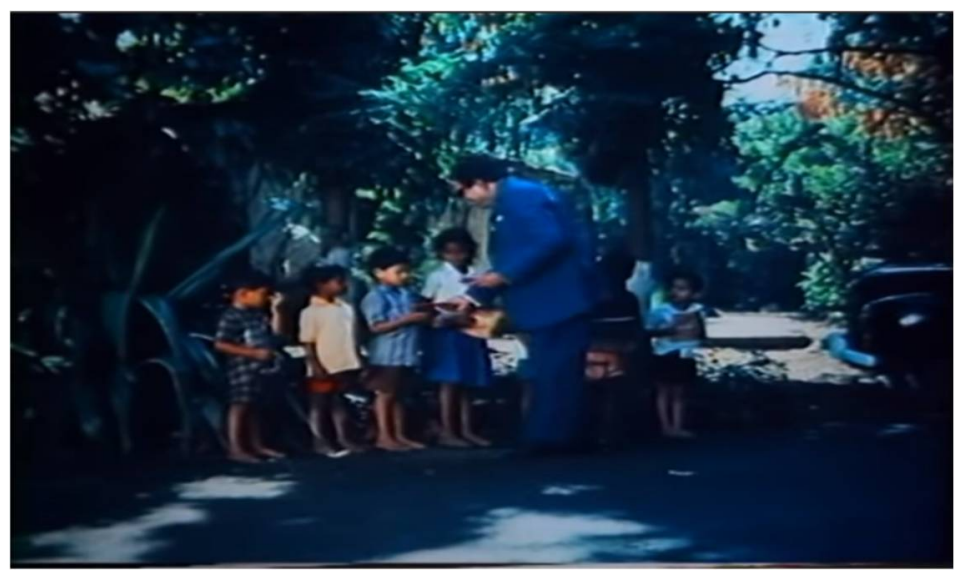

Fig. 11. Still from Pawar, see Bhim Garjana (o1:38:45)

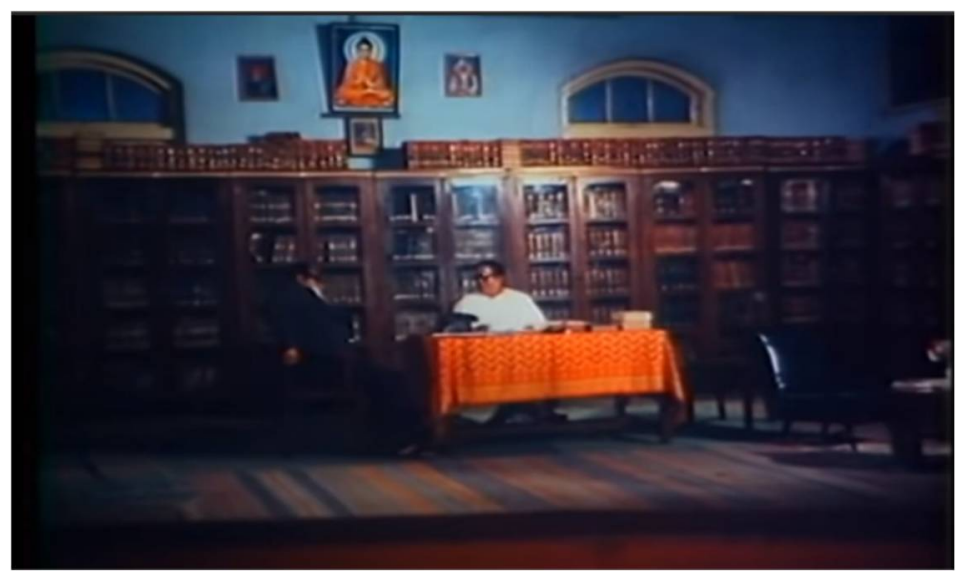

Fig. 12. Still from Pawar, see Bhim Garjana (o1:35:20)

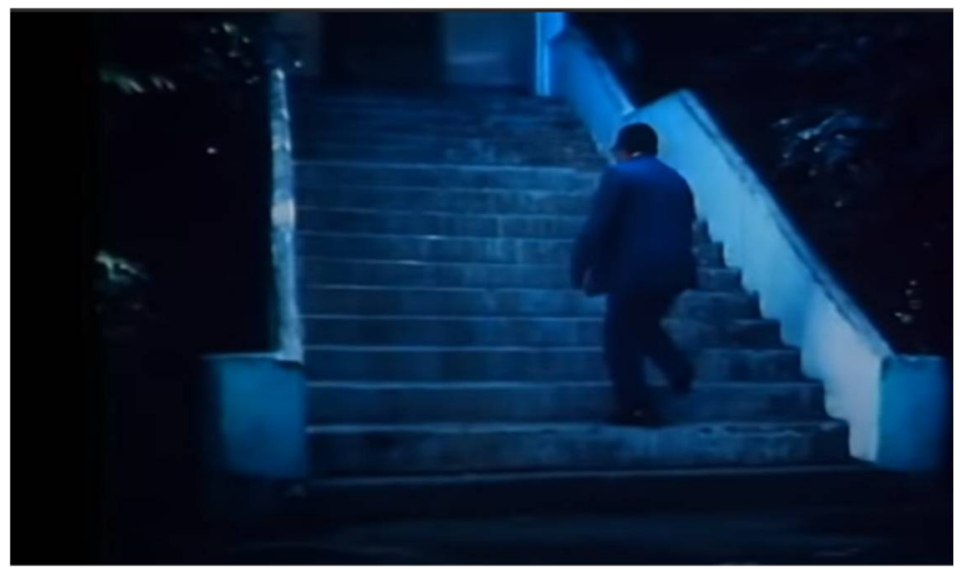

Fig. 13. Still from Pawar, see Bhim Garjana (01:39:05)

Fig. 13 can be read as Pawar visualizing Ambedkar's dream of an educated society. Fig. 11 depicts the visual semantics of that dream of Ambedkar. Fig. 12 is also a kind of intensification of that wish of Ambedkar that prioritizes library space over the space of any other religious space viz. temple. Pawar verbalizes the emptiness of religious spaces or spaces that signify religion through the exchange between Ambedkar and Ramabai. 
Ambedkar: Rama, the pandurang which you desire to have darshan of, with so much faith and devotion, that Pandurang is not a sanctioned place for us. Those people will not allow us entry inside the temple premises.

Ramabai: No worries! I will have darshan from outside the temple premises itself. (01:33:37 - 01:34:18)

Temple, in this film, is cinematically depicted as a negative and disabling space for Dalits. The film moves from the temple space to library space signifying mobility in society from 'old Pandarpur' to 'new Pandarpur' based in the ideals of niswarth-sewa and sadachari- jivan and with the objective of sacrifice for the downtrodden Dalit society. It is here, that the idea of walking out again surface when Ambedkar proposes his wish of 'not dying as a Hindu'!

Pwar adopts the strategy of visual juxtaposition in the space occupied by Ramabai (refer fig. 14, where Ramabai is depicted hand-folded in front of the images of the Hindu deities hanging on the wall, seeking forgiveness for Ambedkar for attempting blasphemy against Panduranga, the local Hindu deity) and Ambedkar in the sequence (refer fig. 12, where the wall of Ambedkar's library is adorned with the image of Buddha and not any Hindu deity).

The images of Hindu deities on the wall in fig. 14 and the image of Buddha in fig. 12 in film cinematically suggest how there is not only a need to recreate the private spaces of Dalit household but also to recreate their notion of worship. ${ }^{\text {xiii }}$

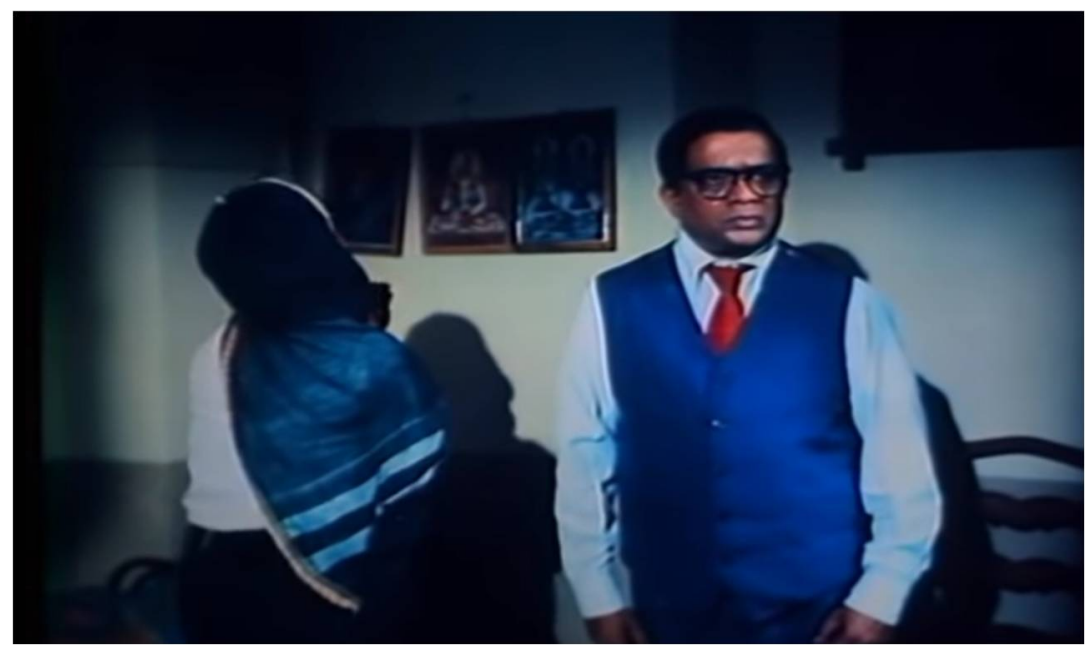

Fig. 14. Still from Pawar, see Bhim Garjana (o1:34:38)

It appears that the overall semiotic analysis of the film by Pawar is a visual encoding of Ambedkar's ideology encapsulated in Ambedkar's slogan "organize, agitate and educate".

The last sequence of the film visualizes the very decision Ambedkar took to walk out of Hindu religion and adopt Buddhism. Ramabai, after she dies, is projected as the force which keeps the idea of new Pandarpur alive. The psychological fall, descent of downfall is compensated by symbolic intrusion of Ramabai in the form of flashback, she reminds him of all the sacrifice Ambedkar has done for the upliftment of Dalits. She reminds him of the hope of millions of Dalits from Ambedkar against the dehumanization of Dalits. Pawar visualizes the moment of Ambedkar's decision to convert into another religion as the moment of some divine intervention. 


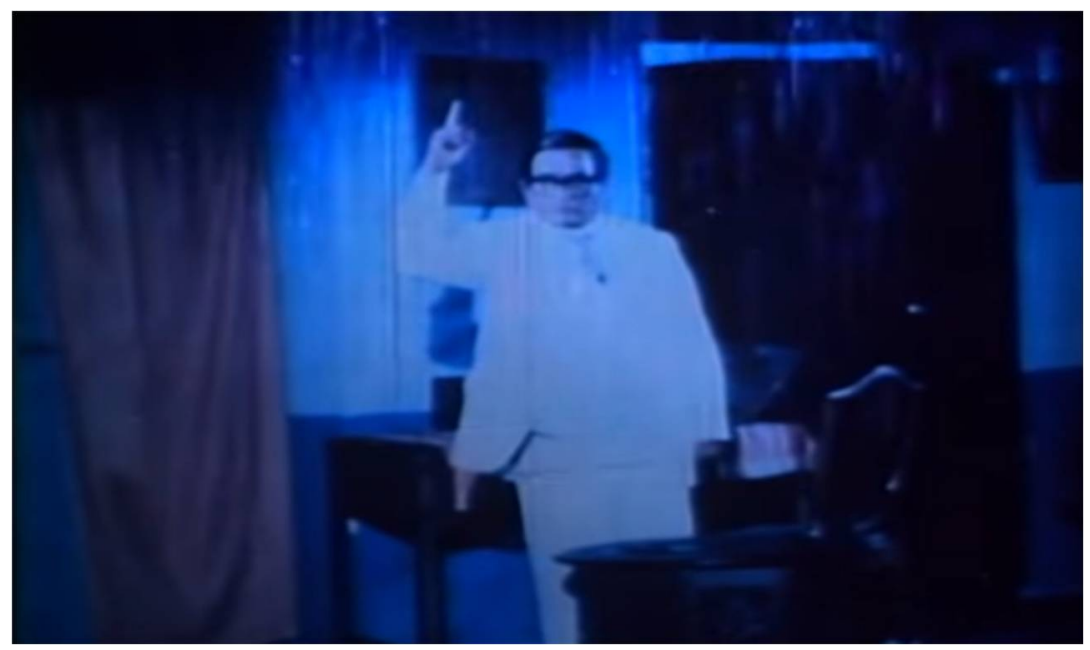

Fig. 15. Still from Pawar, see Bhim Garjana (01:58:19)

The literal garjana of Bhimrao Ambedkar is constructed visually with an image of Buddha and the gathering of his people in the foreground and Buddhist song mixed with Ambedkar's voice message to his people in the background. The gods are changed. The image of Hindu deity is dislodged from the wall (that is the image whose front is turned towards the wall as seen in fig. 15). At the end it signifies the closed-ness of Dalit cognition to the 'past' and signifies the opening of new spaces, new experiences and new articulations for Dalits. Ambedkar's story visualized by Pawar in cinema is an instance where Dalits attempt not only to 'project' the authenticity of their spatial, experiential, cultural, ideological and epistemological self but also to 'protect' it.

\section{NOTES}

' Kancha Illaiah's "Towards the Dalitization of Nation" in Wages of Freedom: Fifty Years of the Nation-State edited by Partha Chatterjee.1998.

ii Limbale, Sharan Kumar. Towards an Aesthetics of Dalit literature: History, Controversies and Considerations. Trans. and Ed. By Alok Mukherjee. New Delhi: Orient Black Swan, 2010.

iii Habermas, Jurgen. The Structural Transformation of the Public Sphere: An Inquiry into a Category of Bourgeois Society. Translated by Thomas Burger. Great Britain: Blackwell and Polity Press. 1989.

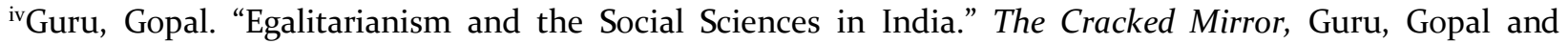
Sarukkai, Sundar, Oxford University Press, 2012, pp. 9-29.

v This is the image coming from Maharashtrian nomadic tribe of Portaj worshipping a goddess called "Kodak Lakshmi". While women perch a small platform on their heads upon which they mount their deity, and play the dhol, men dance and twirl to the beats and flagellate themselves with the heavy knotted whips made of jute, leather or woven coir. The whip generally weighs about ten kilograms. Also known as Dombari community, this community has inclination towards music with certain knowledge of ragas as well such as Dombakriti, Dombkriya, Dombakri.

vi Guru, Gopal. “The Idea of India: 'Derivative, Desi and Beyond'." Economic and Political Weekly, vol. 46, no. 37, 2011, pp. 36-42. JSTOR, www.jstor.org/stable/23047279. Accessed 27 Jan. 2021. 
vii Ibid.

viii This tradition ranges from the Buddha in the ancient period, through Kabir and Tukaram in the medieval, to Jotirao Phule in the modern period, as described in the article titled Experience, Space, and Justice by Gopal Guru, pp.74.

ix This idea of Mobility needs to be understood in terms of its reference of Movement and Mobilization. The movement from one place to another do engender a sense of change or moving out of the geographically stratified cultural, social, political existence. "1989: David Harvey's Postmodernity: The Space Economy of Late Capitalism." The Condition of Digitality: A Post-Modern Marxism for the Practice of Digital Life, by Robert Hassan, University of Westminster Press, London, 2020, pp. 13-34. JSTOR, www.jstor.org/ stable/i.ctvwid5ko.4.

${ }^{x}$ Ambedkar, B.R., Writings and Speeches, vol. 17 (i), pp. 3-50. Dr. Ambedkar Foundation: New Delhi, January, 2014.

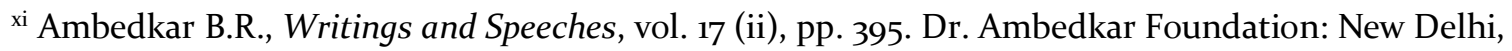
January, 2014

xii Ibid.

xiii Eck, Diana L. Darśan: Seeing the Divine Image in India. Motilal Banarsidass, 2007.

\section{WORK CITED}

Bhim Garjana. Directed by Vijay Pawar. Performance by Krishnanand, Prathma. Ambedkar Films. 1989.

Alexander, Lily. "Storytelling in Time and Space: Studies in the Chronotope and Narrative Logic on Screen." Journal of Narrative Theory, vol. 37, no. 1, 2007, pp. 27-64. JSTOR, www.jstor.org/stable/41304849.

Appadurai, Arjun. Modernity at Large: Cultural Dimensions of Globalization. Oxford University Press, 1997.

Barthes, Roland. Elements of Semiotics. Trans. Annette and Colin Smith. Jonathan Cape, 1967.

Benjamin, Walter. The Work of Art in the Age of Mechanical Reproduction. Translated by J.A. Underwood. Penguin Books, 2008.

Chatterjee, Partha. The Nation and Its Fragments. Princeton University Press, 1992.

Choudhary, Soumyabrata. Ambedkar and other Immortals. Navayana, 2018.

Guru, Gopal and Sundar Sarukkai. The Cracked Mirror: an Indian Debate on Experience and Theory. Oxford University Press, 2012.

Habermas, Jurgen. The Structural Transformation of the Public Sphere: an Inquiry into a Category of Bourgeois Society. Translated by Thomas Burger. Blackwell and Polity Press, 1989.

Jaffrelot, Christopher. India's Silent Revolution: The Rise of Lower Castes in North India. C. Hurst \& Co, 2003.

Jameson, Fredric. The Political Unconscious: Narrative as a Socially Symbolic Act. Routledge, 2002.

Lefebvre, Henri. The Production of Space. Translated by Donald Nicholson-Smith. Blackwell, 1991.

Mirzoeff, Nicholas. The Visual Culture Reader. Routledege, 1998.

Panofsky, Erwin. Meaning in the Visual Art. University of Chicago Press. 1982.

Poole, Deborah. Vision, Race and Modernity: A Visual Economy of the Andean Image World. Princeton University Press, 1997.

Rao, Anupama. The Caste Question: Dalits and the Politics of Modern India. California University Press, 2009. 
Roberge, Gaston. Another Cinema for Another Society. Calcutta: Seagull, 2005.

Yengde, Suraj and Teltumbde, Anand, ed. The Radical in Ambedkar Critical Reflections. Penguin Random House, 2018. 